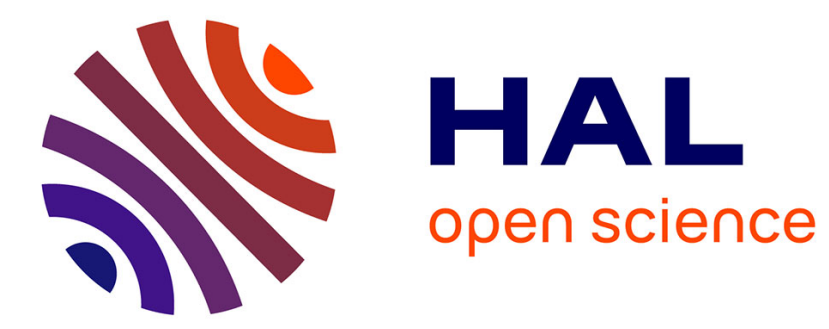

\title{
What Future for the Concept of Culture in the Social Sciences?
}

Alexander Frame

\section{To cite this version:}

Alexander Frame. What Future for the Concept of Culture in the Social Sciences?. Epistémè : revue internationale de sciences humaines et sociales appliquées / , 2017, 17. hal-02059816

\section{HAL Id: hal-02059816 https://hal.science/hal-02059816}

Submitted on 27 Dec 2020

HAL is a multi-disciplinary open access archive for the deposit and dissemination of scientific research documents, whether they are published or not. The documents may come from teaching and research institutions in France or abroad, or from public or private research centers.
L'archive ouverte pluridisciplinaire HAL, est destinée au dépôt et à la diffusion de documents scientifiques de niveau recherche, publiés ou non, émanant des établissements d'enseignement et de recherche français ou étrangers, des laboratoires publics ou privés. 


\section{What Future for the Concept of Culture in the Social Sciences?}

Alexander Frame ${ }^{1}$

\section{Abstract}

This article reviews current criticism of the concept of culture among academics, identifying the misuses and the social context which have led to calls for it to be abandoned. Drawing extensively on recent critical approaches to the concept, it outlines a complex multi-level approach avoiding the traps of determinism and methodological nationalism, allowing us to better understand and deal with contemporary debates and discourses surrounding culture, in the light of which it appears ever more important that social science scholars make their voices heard.

\section{Keywords}

Culture, communication, critical intercultural theory, determinism, social discourse.

\section{Introduction}

The concept of culture is paradoxically (a) one of the most successful concepts to have emerged in the social sciences over the course of the last century, (b) particularly useful to help us understand many contemporary topics of social debate, such as populist xenophobia, discourse surrounding migration, globalisation, national identity and so on, and (c) strongly criticised within the social sciences themselves, where many academics reject the concept outright. Indeed, it is in part the success of the concept itself outside the academic sphere, and the way that it is used by the media, politicians, and in the public sphere more generally, which has triggered this state of affairs. For example, media coverage and (right-wing) political debate about the so-called "refugee crisis" in Western Europe tends to give a very rigid and category-based view of cultures and cultural differences, in which the (stereotyped) cultural practices of arriving "waves" of migrants threaten dominant models of the majority in "host" society, with which they appear incompatible.

Although such discourse has no apparent scientific ambitions, many fear that its (mis)use of the concept of culture is harming the concept itself, a concept which, because of its success in the academic sphere also, has proven hard to define across disciplines, and which has had trouble keeping abreast of evolving conceptions of social interactions. Consequently, there is an increasing number of critical voices (Dervin, 2011, 2013; Dervin \& Machart, 2015a; Holliday, 2015; Wagener, 2015) which are today warning scholars away from a concept presented as insufficiently precise, and accused of emphasising differences and masking the true complexity of the social processes it is supposed to explain. They denounce a tendency, even in research, to reduce individuals to a fixed cultural category, which may have very little bearing on their behaviour in microsocial interactions. By rejecting the concept, they claim, not only will we be better able to come to terms with the complexity of individuals and their social activity, but we will stop giving scientific legitimacy to a term which is commonly exploited to socially construct difference and maintain tensions within societies.

This article outlines the contemporary scientific debate around the concept of culture, reviewing the main objections to the concept, and seeking to explain why and how it can and must be still used to combat the reductive and simplistic discourse which is at the root of much of the criticism. Indeed, the position defended in this article is that only by focusing on the complex multi-level relationship between cultures and communication, can we promote a better understanding of the social world

\footnotetext{
${ }^{1}$ Alex Frame is Associate Professor of Communication Science at the University of Burgundy (Dijon, France), member of the "Texte, Image, Langage" research group. Alexander.Frame@u-bourgogne.fr.
} 
around us, fighting against ignorance in order to overcome simplistic discourses of cultural determinism.

\section{Criticism of the Culture Concept}

The concept of culture has indeed been one of the most productive concepts in the Human and Social Sciences over the course of the twentieth century (Cuche, 1996), at least in terms of the number of fields in which it has been used. From Social and Cultural Anthropology in the early twentieth century, the concept spread to other social sciences, notably from the Sixties onwards (Bauman, 1999, p. viii), and rapidly moving from the domain of scientific jargon into popular discourse, to the point where, as Dervin and Machart (2015b, p. 1) note, it was declared "Word of the Year" by the Merriam-Webster dictionary in 2014. However, at the same time, critical voices were being raised in academic circles, calling for the concept to be abandoned. Indeed, from being what was already a notoriously polysemic term, according to Dervin and Machart its popularity has made it into a dangerous "floating signifier" today (2015b, p. 2), a pseudo-scientific term without a clear or fixed meaning, which leaves it open to all kinds of misuses. Already in 1999, Ulf Hannerz had denounced what he saw as increasingly pervasive "culturespeak", by which he broadly meant inappropriate and reductive or deterministic use of the concept. Even if we set aside definitions of culture "with a capital C", linked to the Arts, heritage and intellectual excellence, and situate ourselves in the descriptive anthropological tradition, uses such as "service culture", "digital culture" or "mobile phone culture" seem to reduce it to the idea of shared knowledge, norms, practices and representations, even attitudes and values, but the all-important link with the particular social group sharing this culture is lost.

Indeed, although the concept was central in anthropology for many years, it has now become strongly contested even within this discipline (Anderson-Levitt, 2012; Kuper, 2001). The idea that the members of a society or social group all share the same cultural references has revealed its limits in studies of (post-)modern societies characterised by the diversity of their populations and a certain liquidity (Bauman, 2011) in the identity choices people make. For many anthropologists, the concept with its homogenising overtones is not sufficiently dynamic to capture the complex social processes and contexts within which people evolve today. For this reason, Arjun Appadurai prefers to employ the adjective "cultural" rather than the more static noun (Appadurai, 2001, pp. 40-47), referring to "cultural traits" which he defines as "a difference which refers to something local, concrete and meaningful" (ibid. p42). Jean-Loup Amselle points out that even terms such as "creolisation", "hybridisation" or "métissage" still implicitly refer to the myth of "pure" cultures:

It is not enough to suggest that all cultures are creolised or have undergone métissage to escape from this dead end, since supposing that each culture has multiple origins brings us straight back to the distinction between different cultures, the idea that we're trying to set aside. Only total cultural agnosticism, i.e. the desire to detach all forms of thought from any particular origin, allows us to escape from this circular reasoning. (Amselle, 2001, pp. 205-6). ${ }^{2}$

\section{Culture as Structure and Praxis}

In order to better understand the debates and criticisms surrounding the concept of culture, it is important to take into account its fundamental duality, in that it both structures our social interactions

\footnotetext{
2 "Il ne suffit pas non plus d'affirmer la créolité ou le métissage de toutes les cultures pour sortir de cette aporie, car supposer une multi-origine de chaque culture reconduit précisément la distinction entre les différentes cultures, dispositif que l'on entend justement écarter. Seul un agnosticisme culturel absolu, c'est-à-dire la volonté de débrancher toute forme de pensée d'une origine quelconque, permet d'échapper à ce cercle". My English translation.
} 
and is performed through them. Paraphrasing Edward Hall, cultures shape our communication, and our communication in turn shapes our cultures. ${ }^{3}$ Zygmunt Bauman expresses this idea, and the tensions between conformism and non-conformism underlying our everyday social interactions when he observes that culture as praxis: ${ }^{4}$

is as much about inventing as it is about preserving; about discontinuity as much as about continuation; about novelty as much as about tradition; about routine as much as about pattern breaking; about norm-following as much as about the transcendence of norm; about the unique as much as about the regular; about change as much as about monotony of reproduction; about the unexpected as much as about the predictable. (Bauman, 1999, p. xiv).

Here, Bauman is echoing Anthony Giddens' vision of the duality of structure, which Giddens expressed in the form of Structuration Theory (1987), reminding us that when individuals produce symbolic acts (speech, actions), they are unconsciously referring to various rules and norms, but the fact of doing so means that the rules and norms themselves are being maintained and possibly updated. The system which structures behaviour is itself reproduced through the behaviour it structures.

If we consider it as structure, then, it is important to note that culture is not stable, but a dynamic process. As Dominique Desjeux points out: "Culture is both structure and something dynamic, which is what makes it so hard to observe and analyse. As structure, it includes stable elements which can give the impression that it has an essence, whereas in fact this stability results first and foremost from the fact that historically things change over long periods. As a dynamic process, it is indeed subject to historical change" (Desjeux, 2002, p. 2). ${ }^{5}$ Failure to seize this complexity has led to many misunderstandings and the idea that culture is something which determines behaviour. Unhelpful but commercially successful metaphors, such as Hofstede's "software of the mind" metaphor of culture ${ }^{6}$ have tended to reinforce such misconceptions.

However, despite the critical voices, most recent scientific research using the culture concept claims to have taken its "structuralist turn" in order to take into account the process-based nature of the concept. Unfortunately, this is not always followed up in the studies themselves, where careless "culturespeak" can sometimes lead to confusion about what belongs where: considerations of supposed pan-cultural characteristics (macro-level) are projected onto individuals in a social interaction (micro-level) without taking into account the fact that individuals adapt their behaviours to situations and to one another, that in their interactions people do not act towards foreigners in the way they would towards people from their own country, and so on. Whereas some of his colleagues call for the concept to be abandoned completely in modern anthropology, Dominique Desjeux suggests

\footnotetext{
${ }^{3}$ In the Silent Language, Hall famously states, "Culture is communication and communication is culture" (Hall, 1959, p. 186).

${ }^{4}$ The title of this section is inspired by Bauman's book Culture as Praxis. The term praxis is used here to refer to culture which exists through practice: it is only through behaviour marked by culture that culture is maintained, passed on and renewed.

5 “La culture est à la fois une structure et une dynamique, c'est ce qui rend son analyse et son observation si difficile. Comme structure elle comprend des éléments stables qui peuvent donner l'impression d'une essence alors que cette stabilité relève surtout de la longue durée historique. Comme dynamique elle est soumise au changement et à l'histoire". My English translation.

${ }^{6}$ Geert Hofstede is probably the most successful author in the field of cross-cultural communication, and his bestselling publication aimed notably at business leaders, in which he describes his "dimensional model" of culture is entitled: Cultures and Organisations: Software of the Mind (Hofstede, Hofstede, \& Minkov, 2010).
} 
that it is enough to pay careful attention to the different "scales of observation" one is employing, which correspond to the "structural" and "dynamic" dimensions of culture:

The question of scales helps us to resolve at least some of the difficulties linked to observing culture: what we can observe on the macro-social scale, and which allows us to identify the regularities of a culture, disappears on the micro-social scale where behavioural and cultural differences are dominant. Both hold true at once, and that is what is most troubling and even hard to accept, but it does allow us to better understand the validity and the limits of each approach to culture. Observation Scales Theory is an anthropological approach which allows us to grasp these different perspectives". (Desjeux, 2002, p. 3). ${ }^{7}$

\section{Ideological Uses of the Notion of Culture}

In his book Liquid Culture, Zygmunt Bauman (2011, pp. 1-17) identifies different uses of the notion of culture in different historical periods and distinguishes four of these: culture as Enlightenment (intellectual progress), culture as global domination (Elias's civilization process), culture as homeostasis and maintenance of group boundaries (linked to Bourdieu's distinction), and culture as personal invention (liquid modernity, multicultural societies). In each period, claims Bauman, the conception is given a particular ideological nuance: linked to rationalism, imperialism, elitism and then relativism respectively, and, except in its liquid version, used to ethically justify various policies and attitudes towards other groups, judged as inferior. Colonialism and imperialism are two of these. Elsewhere, Bauman describes culture as "simultaneously a man-made and a man-making entity" (Bauman, 1999, p. 28), in that it replaces, at least to some degree, supernatural rationalisations of the differences in behaviour, development, wealth, and so on between ethnic groups. Indeed, despite their historical roots, all four ideologies of culture can be found today in discourse among politicians, the media and the public in many Western countries.

Public discourse linked to the question of migration, for example, may often pretext cultural differences to stigmatise, exclude or devalue members of migrant communities. Such discourse may oscillate between a denial of the legitimacy of differences (we're all the same underneath: everyone should be treated equally and be held to respect the same rules and norms) and the idea that the differences which are attributed to these groups somehow constitute unassailable symbolic boundaries to their "integration" in a so-called "host" society. In a circular logic which has been analysed by Fredrik Barth (1969), very often the values, beliefs and practices held up as models for a particular host society are chosen in the light of the cultural differences being denounced and used to draw up and maintain symbolic boundaries between the majority and the minority groups who are being targeted. To quote Dominique Desjeux once again, "culture, which can be the key to adapting to someone, can just as easily be used as a means to deny them their existence" $\left(2002\right.$, p. 6). ${ }^{8}$

By taking on a false air of scientific discourse, such arguments based on "culture" and "diversity" often contribute to maintaining boundaries and creating ghettos within society. Even though it is often associated with the political right, such deterministic discourse can also be employed by the defenders

\footnotetext{
7 “La question des échelles permet de résoudre une partie des difficultés liées à l'observation de la culture : ce qui est observé à l'échelle macro-sociale et qui permet de repérer les régularités d'une culture, disparaît à l'échelle micro-sociale où les diversités culturelles et comportementales dominent. Les deux sont vrais en même temps et c'est cela qui est troublant, voire difficile à accepter, mais qui pourtant permet de mieux comprendre la portée et les limites de chaque approche culturelle. La théorie des échelles d'observation est une approche anthropologique qui permet de comprendre la diversité des approches ". My English translation.

8 "La culture peut autant être une clé pour mieux fonctionner avec l'autre qu'un moyen de le nier." My English translation.
} 
of multiculturalism and even by self-appointed spokespeople of the minority groups themselves, seeking to give themselves political legitimacy and have their voices heard. Although it was long opposed to hegemonic universalism, cultural relativism paradoxically shares the same faults when it is used to promote or justify hegemonic practices in the name of the right to difference, as Albin Wagener explains (2015, pp. 147-57). In "multiculturalism" we find the term "culturalism": claiming and defending a particular "cultural identity" very often leads to reducing this to a set of fixed and recognisable symbols, which are more or less "traditional", "authentic", or invented in a dynamic process of boundary maintenance (Barth, 1969).

This can be illustrated by the cultural appropriation debate, when often self-designated representatives of a minority or underprivileged social group accuse non-members of trying to illegitimately appropriate its cultural codes, often in order to make a profit. The British music group Coldplay and American pop stars such as Taylor Swift, Miley Cyrus and Katy Perry have come under such criticism in recent years, ${ }^{9}$ but the debate even extends to which children can legitimately wear which costumes at Halloween or for Carnival celebrations in the US and elsewhere. Such tensions show just how far things can go when cultural identity claims are taken for absolute truths. North-American multiculturalism is certainly an extreme example of this, but one which is symptomatic of a more general ideological tendency towards more "solid", essentialist (Dervin \& Machart, 2015a), deterministic and reductive approaches to the question of cultural identity.

Even in the academic field of intercultural education, Martine Abdallah-Pretceille remarked, over ten years ago, that "the relatively recent recognition of cultures has led to a totalitarian stance towards the cultural dimension, by reducing individuals to their cultural groups and by overestimating the importance of the cultural dimension". (Abdallah-Pretceille, 2006, p. 2)..$^{10}$ The same comments also apply to scholarly work in other fields, where methodological nationalism (Dervin, 2014; Wimmer \& Glick Schiller, 2002) ${ }^{11}$ is a limit to be avoided at all costs. As Fred Dervin and Régis Machart regret, too often the concept of culture has become "the easy-and-ready-to-be-used explanation for almost everything, the click-and-use application which apparently makes life easy without wondering if we really need it or if it is scientifically or ethically justified" (Dervin \& Machart, 2015b, p. 5).

So should we reject this concept, which has become intellectually too vague, too dangerous, as many authors suggest? Without seeking to belittle the risks or undermine the objections presented above, our answer to this question is negative, since that would also mean abandoning it to those who seek to exploit the term in essentialist ways, through ignorance or in order to further their political, social or commercial agendas. We thus adopt the same line as Ulf Hannerz did, back in 1999 (Hannerz, 1999, p. 396), despite the fact that little or nothing seems to have improved in the meantime. We defend the idea that we can still best combat these misuses of the term by promoting a more rigorous and complex use of the concept, taking into account the different scales of observation (supra), but also the fact that essentialist representations of cultures exist out there in society and play a role in the way we relate to one another on a daily basis.

\footnotetext{
${ }^{9}$ Cf. https://www.theguardian.com/music/2015/apr/17/hunger-games-amandla-stenberg-criticises-mileycyrus-taylor-swift-cultural-appropriation. Page consulted on 31/03/2017.

10 "La reconnaissance, relativement récente, des cultures tend à une « dictature » du culturel par réduction de I'individu à son appartenance culturelle, par une survalorisation de la dimension culturelle”. My English translation.

${ }^{11}$ Methodological nationalism consists in treating nationality, in experimental design, as the sole independent variable which may explain variations in observed behaviour: the fact of comparing different national populations may make the researcher blind to intra-national variations, or cause him/her to attribute differences between corpora to national culture, whereas other factors may (also) be involved.
} 


\section{Culture as a Social Construction and a Communication Toolkit}

The trap of methodological nationalism prevents us from defining an individual by his/her claimed or supposed membership of one single social group - migrants are not simply migrants, any more than they are simply Turks, Russians or Chinese, and it would be extremely hazardous to predict behaviour based on such identifications (cultural reductionism or determinism). However, such reliance on cultural identifications is an everyday occurrence in the social world, where we tend to unthinkingly use various categories to define ourselves and others in order to predict behaviour and anticipate reactions. In this sense, the concept of culture is a social reality, used to make sense of the social world around us and corresponds to a basic human need to think in terms of categories. As Adrian Holliday puts it, "While culture may not be real in the solid, essentialist sense, it is real in the way in which it is used and as an excuse, and very often real in the minds of those who use it". (Holliday, 2015, p. 199). It follows that this concept should be apprehended not as an ontological category, but as a social construct, as the source of heuristic and discursive categorisations. In an article devoted to the question of regional identities, Pierre Bourdieu (1980, p. 65) reminds us that our "representations of reality" (la réprésentation du réel) are just as important as reality itself, since symbolically the representations are what we use to make sense of things.

Social psychology has extensively documented and commented upon the process of social categorisation and the associated intergroup identity processes (Moscovici, 2000; Tajfel, 1981). Social categorisation works as a sort of "cognitive shortcut", an easy way for the brain to divide up the unthinkable complexity of the world into groups, classes and categories which make it easier to apprehend. This way of thinking encourages us to consider individuals that we've identified as members of a particular group, based on their membership of this group and of the traits which we expect them to share, on the basis of their membership, with other members of the same group. The more different a group appears to be to our "own" group - perceived differences which we often explain away through culture - the more members of that group may tend to appear alike. The use of stereotypes to represent the members of groups with which we are not very familiar is a salutary cognitive reaction when faced with the potential anxiety which is associated with high levels of behavioural and predictive uncertainty in interactions with strangers (Gudykunst 1995). Simplifying the complexity through the use of stereotypes is a way of making it more familiar and less frightening. In order to help us think about Otherness or communicate with individuals whom we identify as members of a (little-known) out-group, social categorisation comforts us in the idea that the members of such and such a group share a fairly homogenous culture. In other words, this natural cognitive process tends to comfort us in a falsely essentialist and reductive vision of cultures.

The position defended here, however, is that not only is the notion of culture meaningful in peoples' everyday interactions, as a heuristic category based on attributions of social membership, but also that we should not reduce culture to only this: it is not simply a sort of subjective projection without any objective foundation. We believe that the concept is also necessary and useful in order to understand the structural regularity which can be socially expected within a group, on the level of values, beliefs, practices, etc., as long as we distinguish the two scales of observation (supra). Culture as a "representation of reality" is of course idiosyncratic and so does not correspond perfectly to the patterns of socialisation that can be observed by the analyst on the macrosocial level. However, although these patterns can be found and seen to exercise some degree of influence over people's behaviour (from which they are deduced), they are neither uniformly distributed among members of a particular group, nor is the relationship one of deterministic causality: each individual acts differently, depending on the situation, in relation to various cultures and identities, and with a greater or lesser degree of critical distance. 
A useful analogy can be made with language: so that speakers may understand one another, the code needs to be sufficiently regular, regulated and widely-shared among members of the speech community. When speakers use it, they are free to respect or diverge from the various norms concerning register, grammatical correctness, etc., to produce utterances which are more or less "correct" or "nonsensical", to develop their own jargon or sub-code, but the important thing is that all of their utterances will refer implicitly to the shared code, to which they conform to a greater or lesser extent, or against which they are constructed. "Nonsense" would not be "nonsense" (or at least would not make sense as such) if we did not have a standard norm of language against which to measure it. Sometimes it is because we know that a certain type of language or discourse is expected, that we obtain the effect we want by not producing it. And it is not because people share a language that they all say the same thing, or even say things in the same way. However, if there was no (incompletely) shared code, there could not be mutual understanding.

All interpersonal communication relies on culturally pre-figured codes (such as language) and representations, which are to some extent shared by the participants in an interaction, and, which they are expected to understand, to some extent, depending on how closely they are associated with their various identities. All of these elements can be taken as references by the participants to interpret the "meaning" of what is going on and being said, in the light of their understanding of the situation and what is at stake, of their past experiences and relationships with one another, and of a whole set of internal and external factors affecting their perception (Frame, 2012, 2013b, 2014). The "culturally pre-figured" elements can result not only from national culture, but from many other vectors of socialisation. According to Berger and Luckmann (1966), primary socialisation marks the individual's mind, his/her ways of expressing him/herself and of understanding the world, in a way that secondary socialisation does not. It plays a role in structuring cognition during the formative years, and as such has a more profound impact than secondary socialisation, which in turn helps the socially-aware individual to adapt to interactions within previously-unknown groups. Through secondary socialisation, the individual adapts his/her expectations, practices and discourse, learning new codes and new behaviours based on his/her representations of the social groups ${ }^{12}$ and their norms.

It should be clear that the term "culture" is being used here in relation to social groups of various types and sizes, from the couple (Imahori \& Cupach, 2005) or the family (Kiecolt \& LoMascolo, 2003), groups of friends, colleagues from a department or service, to a whole organisation (Frost, Moore, Louis, Lundberg, \& Martin, 1991), a locality, a region, a profession, etc. "In practice, an individual takes part in several cultures" (Chevrier, 2003, p. 27). ${ }^{13}$ The notion of "taking part in a culture" casts the individual in an active role, whereby (s)he draws upon a cultural toolkit (Swidler, 1986) of knowledge and references in order to express him/herself and to make sense of what is going on. Mary Zellmer-Bruhn and Cristina Gibson defend a constructivist vision of the cultural dynamics of interactions, commenting that "whereas the values-based approach tends to view individuals from a single cultural background as having one perspective on each value, the constructivist view indicates that individuals have a toolkit or repertoire of cultural knowledge at their disposal." (Zellmer-Bruhn \& Gibson, 2014, p. 175). The individual selects the cultural "tools" which appear most appropriate, given the situation and the figurative context (Frame, 2013a), rather than being constrained into

\footnotetext{
${ }^{12}$ These social groups are themselves idealisations first encountered during primary socialisation, which help to define the individual's place in society, his/her relationships with others, his/her sense of belonging to the groups (s)he identifies with or not.

13 "En pratique, un individu [...] participe de plusieurs cultures". My English translation.
} 
acting in a particular way, based on his/her primary socialisation background. For this reason, Brewer and Yuki (2014) plead for the necessity of adopting "a situated view of culture":

A situated view of culture is particularly important for understanding the relationship between culture and group process because social interactions in the group context constitute specific social situations. Across the life span, individuals engage in many types of groups - family groups, friendship groups, recreational groups, work groups, large organizations, national groups, and so on - that differ significantly in size, structure, purpose and temporal extension. These group features constitute situational cues that activate cultural knowledge structures appropriate to that particular social context [...]. Thus, we cannot simply assume that the individuals from a particular cultural background bring a single, fixed set of beliefs and values to all group encounters. Rather, to understand the interface between culture and group process, we need to know what cultural meanings are brought to bear in groups that vary in form and function. (Brewer \& Yuki, 2014, p. 4).

Such dynamic, process-based visions of culture, underlining the importance of intersubjective negotiation and social context in the way that cultural traits are mobilised correspond to what Zygmunt Bauman (2011) and Fred Dervin (2011, p. 33) call "liquid" approaches to culture, as opposed to more essentialist and reductive "solid" approaches. They underline the fact that the ways in which we behave are often only very loosely connected, if at all, to the places we grew up or the education we received.

\section{Conclusion}

Communication scholars should be sensitive to the concept of culture on at least three levels in an interaction. They must distinguish between macro-level and micro-level manifestations of culture, between the widely-shared cultural references supposedly commonly held by the members of a particular nation or other social group, and the way that these references may be mobilised, adapted, or neglected in favour of other cultural references or emergent forms of negotiated behaviour, in a given interaction. In this sense, communication begins where culture ends: in the intersubjective negotiations and emergent structures of meaning to which individuals refer in order to make themselves predictable and interpret the meanings that they suppose others are trying to convey, in a given context. However, to do this, the individuals involved also reason in terms of the third level of culture which scholars need to take into account: that of cultural identity as a social construct, with its associated symbolic boundaries. Despite the "liquidity" of the approaches adopted here, "solid" culture remains often in the minds and eyes of those using it to make sense of cultural diversity in terms of "us" and "them". As Dervin and Machart point out, " Often it is not the Other that we meet in intercultural situations, but our imagination of his/her culture as it is conveyed through different types of discourses on which mass (and nowadays social) media tend to focus. Culture then tends to prescribe how these individuals should be seen, met, understood, dealt with, and so on, rather than recognising who they are in their diverse diversities (gender, social class, religion, age, etc.), as an individual Self. " (Dervin \& Machart, 2015b, p. 3).

In order to transcend the dichotomy between solid and liquid approaches to culture, Tania Ogay and Doris Edelmann (2016) propose a third term which can help us conceptualise the relationship between the first two. Ogay and Edelmann propose to compare culture to a "non-Newtonian fluid": a fluid which densifies when subjected to pressure, to the point of becoming almost solid, but which returns to a liquid state once the pressure has been removed. Thus, they write: "Culture is usually liquid, (or gaseous like air), permeating everything in the context, but remaining unnoticed. But when there is pressure (for example through identification/differentiation issues as a result of intercultural contact), culture becomes solid and perceptible, and differences are perceived and performed." (Ogay \& 
Edelmann, 2016, pp. 9-10). This metaphor allows us to account for the ways in which moments of tension or rivalry between groups within society leads to cultural identities being foregrounded and becoming symbolically more "solid" (i.e. both more rigid and reductive, essentialist).

At a time when tensions and conflicts, between ethnic and religious groups, undermine the social cohesion of many societies around the world, when resulting migrations are presented by populist leaders as a threat to supposed cultural homogeneity and their particular brand of nostalgic parochialism, it is more important than ever for scholars not to simply dismiss such discourse out of hand as an misuse of the concept of culture, but to be able to account for it by explaining the mechanisms on which it depends. We should not wash our hands of the concept of culture through intellectual puritanism, just because the concept is being (mis)used socially, since this would also mean passing up our chance to engage with this discourse. Rather we should use our understanding of the social phenomenon at hand in order to fight against such reductionism. In the same way that terrorism which aims to create fear is fuelled by fear itself and the tensions which arise from this, xenophobic populist discourse acts like a vicious self-fulfilling prophecy, giving itself legitimacy by exacerbating social tensions. ${ }^{14}$ Polarising discourse manipulates and solidifies perceived cultural differences behind which each group takes refuge to defend its identity. In order to combat such discourse, it is important to seek to reduce binary "Us versus Them" thinking, to highlight social complexity and question the solidity of cultural identifications. Scholars in the social sciences are in a unique position, with the conceptual knowledge and critical standpoint which allow them to act as mediators in such social conflicts. Rather than turning inwards and dissociating themselves from ongoing social debates involving culture, it is becoming more and more urgent that they stand up and make their voices heard.

\section{Bibliography:}

Abdallah-Pretceille, M. (2006). L'interculturel comme paradigme pour penser le divers. Presented at

the Congreso internacional de educacion internacional, Madrid, 15-17 mars 2006. Retrieved

from http://www.uned.es/congreso-inter-educacion-intercultural/pretceille_frances.pdf

Amselle, J.-L. (2001). Branchements : Anthropologie de l'universelle des cultures (Flammarion). Paris:

Flammarion.

Anderson-Levitt, K. M. (2012). Complicating the concept of culture. Comparative Education, 48(4), 441-454.

Appadurai, A. (2001). Après le colonialisme : les conséquences culturelles de la globalisation. Paris:

Payot.

Barth, F. (1969). Ethnic Groups and Boundaries. Nationality and Nationalism: Area and Period

Studies-Modern Middle East, Asia, Africa, the Americas, Australia, 3.

Bauman, Z. (1999). Culture as Praxis. London: Sage.

\footnotetext{
${ }^{14}$ Indeed, there is a cynical symbiosis between xenophobic populism and Islamist terrorism, which support each other's cause while claiming to fight against one another.
} 
Bauman, Z. (2011). Culture in a Liquid Modern World. Cambridge, UK: Polity Press.

Berger, P. L., \& Luckmann, T. (1966). The Social Construction of Reality: A Treatise in the Sociology of Knowledge (New Ed). Penguin.

Bourdieu, P. (1980). L'identité et la représentation : éléments pour une réflexion critique sur l'idée de région. Actes de La Recherche En Sciences Sociales, $n^{\circ} 35,10$.

Brewer, M., \& Yuki, M. (2014). Culture and Group Processes. Defining the interface. In M. Yuki \& M. Brewer (Eds.), Culture and Group Processes (pp. 1-14). New York: Oxford University Press.

Chevrier, S. (2003). Le management interculturel. Paris: PUF.

Cuche, D. (1996). La notion de culture dans les sciences sociales. Paris: La Découverte.

Dervin, F. (2011). Impostures interculturelles. Paris: L’Harmattan.

Dervin, F. (2013). Le concept de culture - Comprendre et maîtriser ses détournements et manipulations. Paris: L'Harmattan.

Dervin, F. (2014). Au-delà du nationalisme méthodologique : l'interculturel sans essentialisme. Raisons politiques, 54(2).

Dervin, F., \& Machart, R. (Eds.). (2015a). Cultural Essentialism in Intercultural Relations. London: Palgrave Macmillan.

Dervin, F., \& Machart, R. (2015b). Introduction: Omniscient Culture, Omnipotent Cultures. In F. Dervin \& R. Machart (Eds.), Cultural Essentialism in Intercultural Relations (pp. 1-11). London: Palgrave Macmillan.

Desjeux, D. (2002). Les échelles d'observation de la culture. Communication et organisation, (22). Frame, A. (2012). Reframing Intercultural Communication Research: Theories and Approaches to Communicating in a Culturally Diverse World. Epistémé, (7), 65-84.

Frame, A. (2013a). Communication et interculturalité : cultures et interactions interpersonnelles. Paris: Hermès Science Publishing. 
Frame, A. (2013b). De la sémiotique pour penser la complexité de la communication interpersonnelle : l'approche sémiopragmatique des interactions sociales. Revue française des sciences de l'information et de la communication, (3).

Frame, A. (2014). On Cultures and Interactions: Theorizing the Complexity of Intercultural Encounters. In S. Poutiainen (Ed.), Theoretical Turbulence in Intercultural Communication Studies (pp. 29-44). Newcastle-Upon-Tyne: Cambridge Scholars Publishing.

Frost, P., Moore, L., Louis, M. R., Lundberg, C., \& Martin, J. (Eds.). (1991). Reframing Organisational Culture. Newbury Park, Calif.: Sage.

Giddens, A. (1987). La constitution de la société: Eléments de la théorie de la structuration. Paris: PUF. Gudykunst, W. (1995). Anxiety / Uncertainty Management (AUM) Theory. In R. Wiseman (Ed.), Intercultural Communication Theory (pp. 8-58). Thousand Oaks, CA: Sage.

Hall, E. T. (1959). The Silent Language. New York: Anchor.

Hannerz, U. (1999). Reflections on varieties of culturespeak. European Journal of Cultural Studies, 2(3), 393-407.

Hofstede, G., Hofstede, G. J., \& Minkov, M. (2010). Cultures and Organizations: Software of the Mind, Third Edition (3rd ed.). McGraw-Hill.

Holliday, A. (2015). Afterword. In F. Dervin \& R. Machart (Eds.), Cultural Essentialism in Intercultural Relations (pp. 198-202). London: Palgrave Macmillan.

Imahori, T. T., \& Cupach, W. R. (2005). Identity Management Theory. Facework in Intercultural Relationships. In W. B. Gudykunst (Ed.), Theorizing About Intercultural Communication (pp. 195-210). Thousand Oaks: Sage.

Kiecolt, K. J., \& LoMascolo, A. F. (2003). Roots of Identity. Family Resemblances. In P. J. Burke, T. J. Owens, R. T. Serpe, \& P. A. Thoits (Eds.), Advances in Identity Theory and Research (pp. 2740). New York: Kluwer Academic / Plenum Publishers.

Kuper, A. (2001). L'illusion des cultures. Sciences Humaines, $n^{\circ} 13,5$.

Moscovici, S. (2000). Psychologie sociale des relations à autrui. Paris: Nathan Université. 
Ogay, T., \& Edelmann, D. (2016). 'Taking culture seriously': implications for intercultural education and training. European Journal of Teacher Education.

Swidler, A. (1986). Culture in Action: Symbols and Strategies. American Sociological Review, 51(2), 273-286.

Tajfel, H. (1981). Human Groups and Social Categories: Studies in Social Psychology. Cambridge: Cambridge University Press.

Wagener, A. (2015). L'échec culturel : Vie et mort d'un concept en sciences sociales (1st ed.). Brussels: Peter Lang.

Wimmer, A., \& Glick Schiller, N. (2002). Methodological nationalism and beyond: nation-state building, migration and the social sciences. Global Networks, 2(4), 301-334.

Zellmer-Bruhn, M., \& Gibson, C. (2014). How Does Culture Matter? A Contextual View of Intercultural Interaction in Groups. In M. Yuki \& M. Brewer (Eds.), Culture and Group Processes (pp. 166194). New York: Oxford University Press. 